\title{
Effect of Phosphorus Solubilizing Bacteria on Soil Available Phosphorus and Growth and Yield of Sugarcane
}

\author{
Pyone Pyone AYE ${ }^{1,2}$, Pechrada PINJAI ${ }^{1, *}$ and Saowanuch TAWORNPRUEK ${ }^{1}$ \\ ${ }^{1}$ Department of Soil Science, Faculty of Agriculture, Kasetsart University, Bangkok 10900, Thailand \\ ${ }^{2}$ Plant Pathology Research Section, Department of Agricultural Research, Yezin, Nay Pyi Taw, Myanmar
}

("Corresponding author's e-mail: agrprj@ku.ac.th)

Received: 18 June 2020, Revised: 28 December 2020, Accepted: 5 January 2021

\begin{abstract}
Phosphorus solubilizing bacteria (PSB) can increase soil phosphorus (P) availability and improve plant growth, yield, and phosphorus content of several crops. The experiment was conducted to evaluate the effect of PSB on soil available phosphorus, growth, and yield of sugarcane at field conditions. Kosakonia radicincitans (PSB1) and Bacillus subtilis (PSB2) were applied with two different sources of phosphorus fertilizers: Di-ammonium phosphate (DAP) and rock phosphate (RP). The application of PSB with phosphorus fertilizers enhanced the yield from 17.03 to $38.42 \%$ over no application of fertilizer. It also increased the percentage of commercial cane sugar percent (CCS \%) from 4.8 to $19.96 \%$ over control. The application of PSB2 with DAP showed effective results in available phosphorus content in the soil and yield of sugarcane. The PSB population and the available phosphorus contents were higher in treatments when phosphorus was given partly through RP and DAP than the control. The application of phosphorus fertilizer and PSB increased phosphorus fractions in the soil. The addition of phosphorus fertilizer to soil increased all the inorganic phosphorus fractions in soil. The treatments with PSB resulted in statistical differences in total phosphorus concentrations in the soil. The application of PSB with RP (T6, T7, and T8) showed the highest weight among the treatment at the harvesting time. The yield of sugarcane was highest in the application of PSB2 with either DAP or RP (T4 and T7).
\end{abstract}

Keywords: Available Phosphorus, Di-ammonium phosphate, PSB, Rock Phosphate, Sugarcane

\section{Introduction}

Phosphorus $(\mathrm{P})$ is a key nutrient required for the higher and sustained productivity of sugar from sugarcane. Its influence on cane yield and juice quality has been well established and the application of phosphorus has become an essential part of a sugarcane fertilizer program [1]. Next to nitrogen, phosphorus $(\mathrm{P})$ is the second most important macro-nutrient required by the plants. Unlike nitrogen, there is no large atmospheric source that can be made biologically available for $\mathrm{P}$ availability [2]. Phosphorus is rapidly immobilized after addition to the soil as a soluble fertilizer, and thus, it becomes less available to plant. It is reported to be a critical factor of many crop production systems because of the limited availability of soluble forms in the soils [3]. Phosphorus, either by adsorption or chemical precipitation, becomes immobilize or less soluble in soil. Large amounts of $\mathrm{P}$ applied as $\mathrm{P}$ fertilizers get immobilized by the active and rapid chemical reactions with cations such as $\mathrm{Ca}^{2+}$ in calcareous or normal soils to form a complex calcium phosphate $\left(\mathrm{Ca}_{3}\left(\mathrm{PO}_{4}\right)_{2}\right.$ and with $\mathrm{Al}^{3+}$ and $\mathrm{Fe}^{3+}$ in acidic soils to form aluminum phosphate $\left(\mathrm{AlPO}_{4}\right)$ and ferrous phosphate $\left(\mathrm{FePO}_{4}\right)$ which are sparingly soluble precipitates [4]. Therefore, crop plants can utilize only a fraction of applied $\mathrm{P}$ and this makes them poor in performance [5].

A large number of microbial organisms including bacteria, fungi, actinomycetes, and algae exhibit $\mathrm{P}$ solubilization and mineralization ability. Soil bacteria that have been reported to mobilize poorly available phosphorus via solubilization and mineralization include Pseudomonas spp., Agrobacterium 
http://wjst.wu.ac.th

spp., and Bacillus circulans [6]. Other phosphorus solubilizing and mineralizing bacteria include various strains of Azotobacter [7], Bacillus [8], Burkholderia [9], Enterobacter, Erwinia [10], Ralstonia, Rhizobium [11], Rhodococcus, Serratia, Bradyrhizobium, Salmonella, Sinomonas, and Thiobacillus [12].

Inorganic forms of $\mathrm{P}$ are solubilized by a group of heterotrophic microorganisms excreting organic acids that dissolve phosphatic minerals and/or chelate cationic partners of the $\mathrm{P}$ ions i.e., $\mathrm{PO}_{4}{ }^{3-}$ directly, releasing $\mathrm{P}$ into solution [13]. There are strong pieces of evidence that soil bacteria are capable of transforming soil $\mathrm{P}$ to the forms available to plant. Microbial biomass assimilates soluble $\mathrm{P}$ and prevents it from adsorption or fixation [14]. Microorganisms enhance the $\mathrm{P}$ availability to plants by mineralizing organic P in soil and by solubilizing precipitated forms of phosphates [15]. Subsequently, PSB becomes a source of P to plants upon its release from their cells [16]. Seed or soil inoculation with phosphatesolubilizing bacteria (PSB) such as Bacillus spp. can solubilize fixed soil P and applied phosphates, resulting in higher crop yields [17].

Considering the importance of phosphorus nutrition in sugarcane, the experiment was carried out with the objectives of (a) to evaluate the effect of Phosphate Solubilizing Bacteria (PSB) on the available phosphorus in the sugarcane ratoon field, and (b) to access the effect of Phosphate Solubilizing Bacteria (PSB) on sugarcane growth and yield at field condition.

\section{Materials and methods}

\section{Preparation of Phosphorus solubilizing bacteria (PSB)}

The two Phosphate Solubilizing Bacteria strains, PSB1 (Kosakonia radicincitans) and PSB2 (Bacillus subtilis), were isolated from the rhizosphere of sugarcane in previous experiments that can solubilize phosphate, produce Indole Acidic Acid and gibberellic acid in vitro condition [18]. The PSB inoculum was prepared as follows. The two PSB strains were individually grown in nutrient broth (NB) medium (containing peptone $5 \mathrm{~g} \mathrm{~L}^{-1}$, beef extract $4 \mathrm{~g} \mathrm{~L}^{-1}$,) with shaking at $180 \mathrm{rpm}$ for 24 hours at $30{ }^{\circ} \mathrm{C}$, and then the broth was added to the nutrient broth in the volume of $3000 \mathrm{ml}$ and stand 24 hours at room temperature. The population density of the bacteria culture was $0.7-0.8\left(\mathrm{OD}_{600}=0.7-0.8\right)$. The final concentration of PSB inoculum was adjusted to $10^{8}$ colony-forming units $(\mathrm{CFU}) \mathrm{ml}^{-1}$.

\section{Experimental design}

The experiment was conducted in the Manjakhiry soil series (Mki) at Sa Kaeo Province (Latitude: $13^{\circ} 49^{\prime} 8.39^{\prime \prime} \mathrm{N}$ and Longitude: $102^{\circ} 03^{\prime} 19.20^{\prime \prime} \mathrm{E}$ ), Thailand. The Mki soil had a loamy sand texture. Their $\mathrm{pH}$, organic matter content, and available $\mathrm{P}$ content were $6.4,1.63 \%$, and $9.49 \mathrm{mg} \mathrm{kg}^{-1}$, respectively. The experiment was carried out to study the effect of two kinds of Phosphate solubilizing bacteria: PSB1 (Kosakonia radicincitans) and PSB2 (Bacillus subtills) application with two different phosphorus such as di-ammonium phosphate (DAP) and rock phosphate (RP) fertilizers on the changes in the soil available phosphorus level and sugarcane growth. The treatments were the application of nitrogen $(\mathrm{N})$, phosphorus $(\mathrm{P})$, and potassium $(\mathrm{K})$ fertilizers with or without PSB or co-inoculation of 2 species of PSB. Urea as a source of nitrogen was applied at the rate of 135.68 and $150.41 \mathrm{~kg} \mathrm{ha}^{-1}$, DAP as a phosphorus source (37.61 $\left.\mathrm{kg} \mathrm{ha}^{-}\right)$, RP as a phosphorus source (576.56 $\left.\mathrm{kg} \mathrm{ha}^{-1}\right)$, and potassium chloride (KCl) $\left(24.71 \mathrm{~kg} \mathrm{ha}^{-1)}\right.$ as a potassium source. All chemical fertilizer rates were calculated based on the results of soil analysis then were applied in different treatments. The fertilizers were applied 30 and 60 days after ratooning.

The experiment was carried on in the sugarcane ratoon field. The sugarcane cultivar, Khon Kaen 3 was planted in 5 rows with 1.5 meters spacing. The distance between the plants is $0.5 \mathrm{~m}$ apart. The treatments were laid out in a randomized complete block design with three replications. The plot size was $6 \times 6 \mathrm{~m}^{2}$ (5 rows of $1.5 \mathrm{~m}$ spaced $2 \mathrm{~m}$ apart). The treatments included control (T1), N P K (recommended rates) (T2), PSB1 + N P K (T3), PSB2 + N P K (T4), PSB1 + PSB2 + N P K (T5), PSB1 + RP + N K + RP (T6), PSB2 + RP + N K + RP (T7) and PSB1 + PSB2 + N K + RP (T8). Water was supplied by the furrow irrigation method after planting. Diuron pendimethalin and imazethapyr were sprayed for weed control 10 days after planting. Deltamethrin (3\%) was applied one month after planting for pest control. 
http://wjst.wu.ac.th

The phospho-bacteria cultures $\left(10^{8} \mathrm{CFU} \mathrm{m}{ }^{-1}\right)$ were sprayed two and three months after ratooning to the soil at the base of the sugarcane plants.

\section{Plant growth measurement}

Sugarcane growth parameters, including stalk length $(\mathrm{cm})$, stalk weight $(\mathrm{kg})$, and yield (ton), were collected 6 months after planting and harvesting time. For the growth data, 10 plants per plot were selected and measured, and calculated. Juice samples were extracted from the plot at the harvesting time. Brix and sucrose were determined following the standard procedures [19]. From the value of Brix and sucrose, commercial cane sugar percent $(\mathrm{CCS} \%$ ) was calculated as $\mathrm{CCS} \%=1.022 \mathrm{~S}-0.292 \mathrm{~B}$, where $\mathrm{S}$ and $\mathrm{B}$ are sucrose and Brix percent respectively, in the juice [20]. Cane yield data were recorded from the plot and converted yield per hectare.

\section{Soil analysis}

Samples of rhizosphere soil ( 0 - $15 \mathrm{~cm}, 10$ spots in each plot and mixed) were collected from all the experimental plots at 6 months and harvesting time of sugarcane to test the available phosphorus in soil by Bray II method [21]. Total P was analyzed by the Vonado - molybdate method [22] and P fraction were analyzed by the methods of phosphorus analysis [23].

The PSB population in the soil was determined at the same growth stages as sugarcane. The soil samples were serially diluted and spread plated in a petri dish containing National Botanical Research Institute's Phosphate Growth medium (NBRIP) which includes glucose (10), $\mathrm{Ca}_{3}\left(\mathrm{PO}_{4}\right)_{2}(5), \mathrm{MgCl}_{2} .6 \mathrm{H}_{2} \mathrm{O}$ (5), $\mathrm{MgSO}_{4} .7 \mathrm{H}_{2} \mathrm{O}(0.25), \mathrm{KCl}(0.2)$, and $\left(\mathrm{NH}_{4}\right)_{2} \mathrm{SO}_{4}(0.1)$ gram per liter with and without Chloramphenicol $20 \mathrm{ppb}$ to count the inoculated PSB1 and PSB2. The tricalcium phosphate clearing zone forming bacteria colonies were counted as PSB. The population of phosphate solubilizing bacteria was then expressed colony forming unit per gram of soil [24].

\section{Statistical analysis}

One-way analysis of variance (ANOVA) was used to determine significant treatment effects at a 5 $\%$ significance level. The least significant difference (LSD) test was used to determine significant $(P<$ $0.01)$ differences. The data were analyzed by using Statistical Package for the Social Sciences (SPSS) software version 21 .

\section{Results and discussions}

Phosphorus solubilizing bacteria and phosphorus fertilizer effect on phosphorus status in soil

The NPK fertilizer without PSB (T2) and with PSB can increase the available P content in soil when compared with control (Table 1). The application of single PSB with DAP (T3) increased the available P content in soil than control (T1). When the co-inoculation of PSBs was applied with DAP (T5), it was shown a higher amount of available $P$ than single inoculation. In the single inoculation of PSB with DAP, PSB2 (T4) showed a higher available P than PSB1 with DAP (T3). When the PSB was used together with RP as a phosphorus source, the co-inoculation of PSB with RP (T8) showed the highest amount of available P than the single inoculation (T7). PSB2 (T7) also showed a higher amount of available P with a combination of RP than PSB1 (T6). It was indicated that the combined inoculation of bio-fertilizers not only helped in making the phosphorus available from RP, but it may also have helped the solubilization and mobilization of native soil $\mathrm{P}$ or $\mathrm{P}$ fixed from DAP and made it more available to plants [25]. Phosphorus solubilizing bacteria increased $\mathrm{P}$ solubilization of added $\mathrm{P}$ fertilizers either from the soluble or insoluble source. Soluble $\mathrm{P}$ fertilizers i.e., single super phosphate and di-ammonium phosphate displayed the highest $\mathrm{P}$ release capacity compared to insoluble RP and organic poultry manure [26].

The total $\mathrm{P}$ content in soil was highly statistically different in the treatments at all times (Table 1). The total P content was higher in the treatments of co-inoculation of PSB 1 and PSB 2 with DAP (T5) at the 6 months of sugarcane growth. The total P content was the highest amount in the application of NPK only (T2) at the harvesting time of sugarcane. The treatments with PSB resulted in statistically significant differences in total $\mathrm{P}$ concentrations and a significant decrease in the soil total $\mathrm{P}$ content due to microbial 
http://wjst.wu.ac.th

solubilization of inorganic and organic phosphorus forms in soil. This result showed that PSB applications render a part of insoluble phosphate form into soluble forms for plant utilization.

Table 1 Effect of phosphorus solubilizing bacteria and fertilizer treatments on available and total phosphorus content in the soil.

\begin{tabular}{lcccc}
\hline \multirow{2}{*}{ Treatments } & \multicolumn{2}{c}{ Available P $\left(\mathbf{m g ~ k g}^{-\mathbf{1}}\right)$} & \multicolumn{2}{c}{ Total P $\mathbf{( \mathbf { m g ~ k g } ^ { - 1 } )}$} \\
\cline { 2 - 5 } & $\mathbf{6}$ months & Harvesting time & $\mathbf{6 ~ m o n t h s}$ & Harvesting time \\
\hline T1 Control & $29.90 \mathrm{c}$ & $15.11 \mathrm{f}$ & $45.83 \mathrm{c}$ & $51.75 \mathrm{~d}$ \\
T2 NPK & $87.89 \mathrm{a}$ & $53.14 \mathrm{bc}$ & $108.33 \mathrm{a}$ & $176.48 \mathrm{a}$ \\
T3 PSB1 + NPK & $69.56 \mathrm{~b}$ & $47.56 \mathrm{c}$ & $101.38 \mathrm{a}$ & $113.40 \mathrm{bc}$ \\
T4 PSB2 + NPK & $82.06 \mathrm{ab}$ & $73.06 \mathrm{a}$ & $108.33 \mathrm{a}$ & $124.87 \mathrm{~b}$ \\
T5 PSB1 + PSB2 + NPK & $86.22 \mathrm{a}$ & $45.06 \mathrm{~cd}$ & $111.11 \mathrm{a}$ & $169.31 \mathrm{a}$ \\
T6 PSB1 + NK + RP & $42.06 \mathrm{c}$ & $26.39 \mathrm{e}$ & $76.38 \mathrm{~b}$ & $81.86 \mathrm{~cd}$ \\
T7 PSB2 + NK + RP & $69.56 \mathrm{~b}$ & $38.56 \mathrm{~d}$ & $106.94 \mathrm{a}$ & $90.46 \mathrm{bc}$ \\
T8 PSB1 + PSB2 + NK & $74.56 \mathrm{ab}$ & $30.31 \mathrm{e}$ & $94.44 \mathrm{a}$ & $91.90 \mathrm{bc}$ \\
RP & $* *$ & $* *$ & $* *$ & $* *$ \\
\hline F- Test & 11.23 & 10.57 & 10.81 & 18.48 \\
CV \% & & &
\end{tabular}

*Means followed by the same letter in the same column were not significantly different at $p \leq 0.01$ $* \mathrm{CV}=$ Coefficient of variation

The average percent of total phosphorus associated with different fractions in the treatments was in the decreasing order of Fe-P $>$ Al-P $>\mathrm{Ca}-\mathrm{P}$ at 6 months and harvesting time of sugarcane. From the analysis of the proportion of phosphorus in various forms, it was found that the phosphorus was immobilized in the form of iron phosphate followed by in the form of aluminum phosphate and calcium phosphate, respectively. It is found that all the treatments except control result in phosphorus immobilized highly in the form of Fe-P (Figure 1). The application of P fertilizer and PSB can increase the inorganic $\mathrm{P}$ fractions in the soil. The other study showed that the bacterial treatment caused significant changes in the amount of phosphorus, organic phosphorus, and mineral phosphorus. The amount of available phosphorus, organic phosphorus, and mineral form (di-calcium bound phosphate $\left(\mathrm{Ca}_{2}-\mathrm{P}\right)$ ) in bacterial inoculation increased compared to control treatment. In addition, the Al-P form was increased $10 \%$ compared to control in bacteria treatment [27]. 


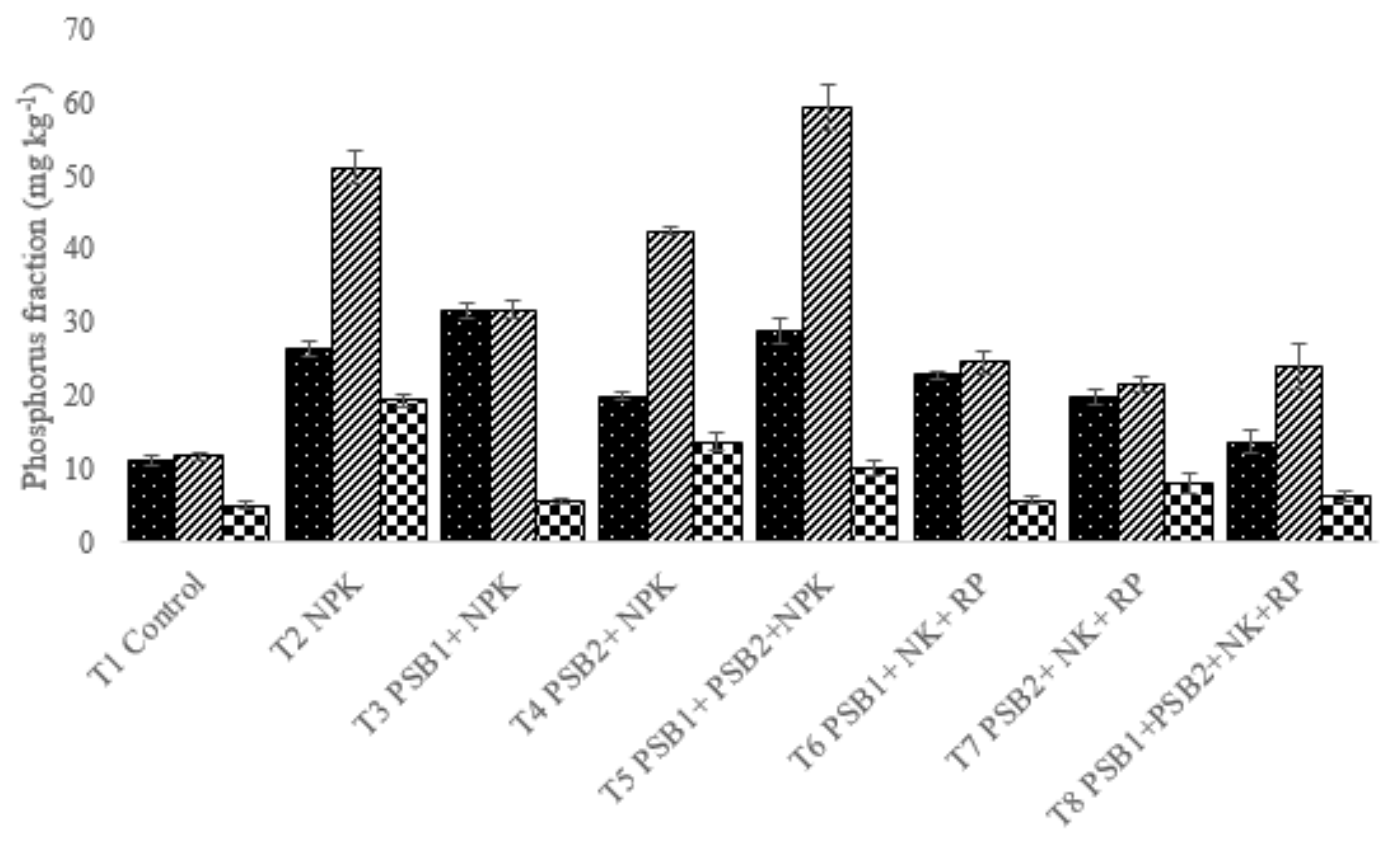

Treatments

-A1-P $\boldsymbol{a} \mathrm{Fe}-\mathrm{P}$ तa-P

Figure 1 Phosphorus fraction in treatments at harvesting time.

\section{Phosphorus solubilizing bacteria and phosphorus fertilizer effect on PSB population}

There were no significant differences in the PSB population in all treatments but the application of PSB can increase the PSB population in the soil when compared with NPK treatment and control (Figure 2). When PSB was applied in conjunction with DAP (T3, T4, and T5) as phosphorus fertilizer, a much greater effect was found at the 6 months of sugarcane over the application of PSB with RP (T6, T7, and T8). The co-inoculation of PSB showed a high number of PSB in the application of any phosphorus fertilizer sources (DAP or RP). The PSB population in treatments involving PSB applications was maintained up to 6 months of sugarcane growth and then lower towards the harvesting time. The PSB population and the available $\mathrm{P}$ contents were higher in treatments when $\mathrm{P}$ was given partly through RP and DAP than the control. The bacterial population decreased from six months to harvesting time of sugarcane. The physical, chemical, and physicochemical nature of the soil and its indigenous microorganisms and predators influence the microbial population both quantitatively and qualitatively. Soil abiotic factors (e.g., texture, $\mathrm{pH}$, temperature, and moisture) exert their (direct) effect on inoculant population dynamics by imposing stresses. On the other side, trophic competitions and antagonistic/synergic and predatory interactions with the resident microbial and fauna populations determine the field efficiency of inoculants. The key factors involved in the lack of success are rapid decline in the size of populations of active cells to levels ineffective to achieve the objective and variable production of required metabolites or poor colonization, following the introduction into the soil [28]. 


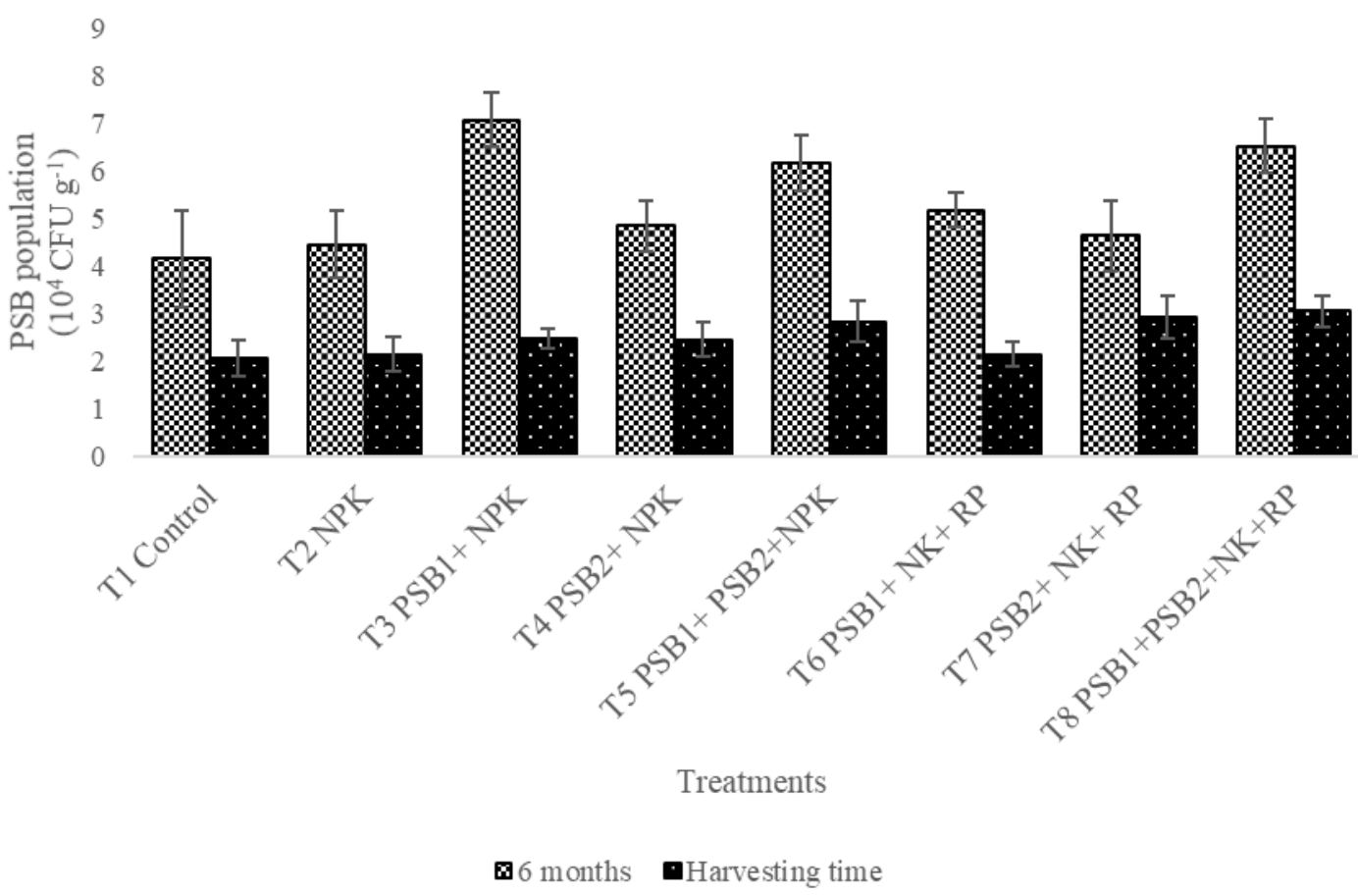

Figure 2 PSB population in the soil at 6 months and harvesting time.

Phosphorus solubilizing bacteria and phosphorus fertilizer effect on yield components, yield, and $\mathrm{CCS} \%$

Effect of PSB and P fertilizer on yield components of sugarcane; stalk length and stalk weight were recorded at 6 months and yield and CCS\% at harvesting time of sugarcane. There were no significant differences in sugarcane parameters (Table 2). The recommended P application with PSB increased the stalk length and stalk weight compared with NPK treatment (T2) and control (T1). The stalk length was higher in the application of PSB with P fertilizer through rock phosphate (T6 and T7) than the DAP fertilizer application (T3 and T4). The application of PSB2 with RP (T7) was the highest in stalk length and stalk weight among all treatments. However, the application of PSB with DAP (T3 and T4) also showed an increase in stalk length and weight over control (T1) and NPK application (T2) only. Another study based on pot experiments demonstrated that bacterially impregnating DAP and urea granules with the Plant Growth Promoting Bacteria (PGPB) Bacillus sp. Strain (KAP6) enhanced growth, yield, photosynthetic rate, and nutrient use efficiency of wheat supplied with $\mathrm{N}$-containing fertilizers such as urea and DAP [29]. Combinatory use of PSM and phosphorus fertilizer has been practiced and some studies evidenced improved agronomic efficiency of rock phosphate and P fertilizers such asDAP, NPK, and TSP [30]. Inoculation of PSMs in soil or seed is known to enhance solubilization of applied and fixed phosphates in soil, resulting in better crop yield [31]. PSMs promote plant growth via generating phytohormones, such as auxins, gibberellins, cytokinins, or polyamides [32].

There were significantly differences in cane yield and $\mathrm{CCS} \%$ of sugarcane in treatments. The application of PSB with P fertilizer sources increased the cane yield over NPK without PSB (T2) and control (T1). The cane yield was highest in the application PSB2 with P fertilizer through DAP (T4) which was followed by the co-inoculation of PSB with DAP (T5) and with RP (T8). The PSB application either single or co-inoculation of PSBs increased the average cane yield from $17.03 \%$ (T8) to $38.42 \%$ (T4) over control. The yields increased in only NPK fertilizer treatment showed an $11.81 \%$ (T2) 
increased over the control (T1). The CCS\% was the highest in treatment when RP as a phosphorus source was applied through with PSB. The co-inoculation of PSB with RP (T8) also showed a higher level of CCS\%. The CCS\% increased from 4.80 to $19.96 \%$ over control in the PSB treatments. The NPK fertilizer (T2) treatment increased $13.11 \%$ in CCS\% compared to control (T1). The authors reported that fertilization with rock phosphate $\left(59 \mathrm{~kg} \mathrm{P}_{2} \mathrm{O}_{5} \mathrm{ha}^{-1}\right)$ and inoculation with two PSB strains induced high growth and yield performances (grains yield, shoot, and root biomass, and P uptake) in wheat and maize [33]. The two PSB strains in the co-inoculation acted synergistically with each other and strengthened the beneficial effects on plant growth performance [34]. Moreover, the benefit of the combined DAP and PSB application improved maize dry matter (12\%), yield, and P uptake (33\%) compared to unfertilized soil. Such a P fertilizer-bacteria alliance approach is particularly interesting in the soil where $\mathrm{P}$ management is demanding [35]. Application of PSM by inoculating in soil appears to be an efficient way to convert the insoluble $\mathrm{P}$ compounds to plant-available $\mathrm{P}$ form, resulting in better plant growth, crop yield, and quality. Bacillus, Pseudomonas, Rhizobium, Aspergillus, Penicillium, and arbuscular mycorrhizal (AMR) are the most efficient P solubilizers for increasing the bioavailability of $\mathrm{P}$ in soil. Application of PSM by inoculating in soil appears to be an efficient way to convert the insoluble P compounds to plant-available P form, resulting in better plant growth, crop yield, and quality. Bacillus, Pseudomonas, Rhizobium, Aspergillus, Penicillium, and AMR are the most efficient P solubilizers for increasing bioavailability of $\mathrm{P}$ in soil [36].

Table 2 Effect of PSB and fertilizer treatments on sugarcane growth, yield, and CCS\%.

\begin{tabular}{|c|c|c|c|c|c|}
\hline \multirow[b]{2}{*}{ Treatments } & \multicolumn{2}{|c|}{ Stalk length (cm) } & \multirow{2}{*}{$\begin{array}{c}\text { Stalk weight } \\
\text { (kg) }\end{array}$} & \multirow{2}{*}{$\begin{array}{l}\text { Cane yield } \\
\left(\text { ton } \mathbf{h a}^{-1}\right)\end{array}$} & \multirow[b]{2}{*}{$\mathrm{CCS} \%$} \\
\hline & 6 months & $\begin{array}{c}\text { Harvesting } \\
\text { time }\end{array}$ & & & \\
\hline T1 Control & 175.97 & 244.63 & 14.07 & $88.53 \mathrm{c}$ & $11.67 \mathrm{~d}$ \\
\hline T2 NPK & 172.80 & 252.07 & 14.80 & $98.99 \mathrm{bc}$ & $13.20 \mathrm{abc}$ \\
\hline $\mathrm{T} 3 \mathrm{PSB} 1+\mathrm{NPK}$ & 176.27 & 254.87 & 14.55 & $102.26 \mathrm{bc}$ & $12.88 \mathrm{abc}$ \\
\hline T4 PSB2 + NPK & 180.17 & 264.83 & 15.30 & $122.55 \mathrm{a}$ & $12.57 \mathrm{bcd}$ \\
\hline $\mathrm{T} 5 \mathrm{PSB} 1+\mathrm{PSB} 2+\mathrm{NPK}$ & 172.63 & 258.77 & 15.31 & $115.28 \mathrm{ab}$ & $12.38 \mathrm{bcd}$ \\
\hline T6 PSB1 + NK + RP & 186.70 & 258.10 & 15.69 & $114.40 \mathrm{ab}$ & $12.23 \mathrm{~cd}$ \\
\hline $\mathrm{T} 7 \mathrm{PSB} 2+\mathrm{NK}+\mathrm{RP}$ & 187.23 & 263.17 & 15.81 & $115.14 \mathrm{ab}$ & $14.00 \mathrm{a}$ \\
\hline $\begin{array}{l}\text { T8 PSB1 + PSB2 + NK + } \\
\text { RP }\end{array}$ & 171.10 & 260.27 & 15.73 & $103.61 \mathrm{bc}$ & $13.48 \mathrm{ab}$ \\
\hline F - Test & ns & ns & ns & $* *$ & $* *$ \\
\hline $\mathrm{CV} \%$ & 6.11 & 20.46 & 8.37 & 9.16 & 4.85 \\
\hline
\end{tabular}

*Means followed by the same letter in the same column were not significantly different at $p \leq 0.01$.

*CV means coefficient of variation.

\section{Conclusions}

The results of this study showed the beneficial effect of PSB application for sugarcane. The application of PSB increased the amount of available phosphorus in the soil. Phosphorus can promote tillering capacity. It can also lead to an increase in stalk number and cane yield. Improvement in juice sucrose and purity was significant by PSB. The average cane yield of the treatments including PSB either single or co-inoculation of PSBs increased yield from the lowest value of 17.03 (T8) percent to $38.42 \%$ (T4) highest value over control. The yields increased in the treatments of recommended NPK fertilizer showed just $11.81 \%$ (T2) over the control (T1). The CCS\% increased from 4.80 to $19.96 \%$ over control in the PSB treatments. The application of recommended NPK treatment increased CCS\% to $13.11 \%$ as compared to control. 
http://wjst.wu.ac.th

\section{Acknowledgement}

I would like to sincerely thanks the scholarship of "The $60^{\text {th }}$ Birthday Anniversary of Professor Dr. Her Royal Highness Princess Chulabhorn Mahidol" for the financial support of this research. I would like to express the depth of my gratitude to my respectable advisor Dr. Pechrada PINJAI for her valuable advice and suggestion and offer of the working facilities.

\section{References}

[1] B Sundara and V Natarajan .Effect of source and time of phosphorus application with and without phosphorus solubilizing bacteria on sugarcane. In: Proceedings of the Annual Convention of SugarTechnology Association of India, Goa, September, 1997.

[2] H McVicker, G Bridger and L Nelson. Advances in phosphate fertilizers technology and usage. Soil Sci. Soc. Am. J. Madison II, Wiscon. 1963, p. 155-87.

[3] MS Khan, A Zaidi and PA Wani. Role of phosphate-solubilizing microorganisms in sustainable agriculture a review. Agron. Sustain. Dev. 2007; 27, 29-43.

[4] N Vassilev, M Vassileva, M Fenice and F Federici. Immobilized cell technology applied in solubilization of insoluble inorganic (rock) phosphates and $\mathrm{P}$ plant acquisition. Bioresource Technol. 2001; 79, 263-71.

[5] SB Sharma, RZ Sayyed, MH Trivedi and TA Gobi. Phosphate solubilizing microbes: Sustainable approach for managing phosphorus deficiency in agricultural soils. SpringerPlus 2013; 2, 587.

[6] OO Babalola and BR Glick. The use of microbial inoculants in African agriculture: Current practice and future prospects. J. Food Agric. Environ. 2012; 10, 540-9.

[7] S Kumar, K Bauddh, SC Barman and RP Singh. Amendments of microbial biofertilizers and organic substances reduces requirement of urea and DAP with enhanced nutrient availability and productivity of wheat (Triticum aestivum L.). Ecol. Eng. 2014; 71, 432-7.

[8] M Jahan, MN Mahallati, MB Amiri and HR Ehyayi. Radiation absorption and use efficiency of sesame as affected by biofertilizers inoculation in a low input cropping system. Ind. Crop Prod. 2013; 43, 606-1.

[9] P Rahi, V Pathania, A Gulati, B Singh, RK Bhanwra and R Tewari. Stimulatory effect of phosphatesolubilizing bacteria on plant growth, stevioside and rebaudioside-A contents of Stevia rebaudiana Bertoni. Appl. Soil Ecol. 2010; 46, 222-9.

[10] U Chakraborty, BN Chakraborty, M Basnet and AP Chakraborty. Evaluation of Ochrobactrum anthropi TRS-2 and its talc based formulation for enhancement of growth of tea plants and management of brown root rot disease. J. Appl. Microbiol. 2009; 107, 625-34.

[11] F Tajini, M Trabelsi and JJ Drevon. Combined inoculation with Glomus intraradices and Rhizobium tropici CIAT899 increases phosphorus use efficiency for symbiotic nitrogen fixation in common bean (Phaseolus vulgaris L.). Saudi J Biol Sci. 2012; 19, 157-63.

[12] J Postma, E Nijhuis and E Someus. Selection of phosphorus solubilizing bacteria with biocontrol potential for growth in phosphorus rich animal bone charcoal. Appl. Soil Ecol. 2010; 46, 464-9.

[13] Z He, W Bian and J Zhu. Screening and identification of microorganisms capable of utilizing phosphate adsorbed by goethite. Comm. Soil Sci. Plan. 2002; 33, 647-63.

[14] KS Khan and RG Joergensen. Changes in microbial biomass and P fractions in biogenic household waste compost amended with inorganic P fertilizers. Bioresource Technol. 2009; 100, 303-9.

[15] YP Chen, PD Rekha, AB Arun, FT Shen, WA Lai and CC Young. Phosphate solubilizing bacteria from subtropical soil and their tricalcium phosphate solubilizing abilities. Appl. Soil Ecol. 2006; 34, 33-41.

[16] EK Bünemann, DA Bossio, PC Smithson, E Frossard and A Oberson. Microbial community composition and substrate use in a highly weathered soil as affected by crop rotation and $\mathrm{P}$ fertilization. Soil Biol. Biochem. 2004; 36, 889-901.

[17] ME Puente, Y Bashan, CY Li and VK Lebsky. Microbial populations and activities in the rhizoplane of rock-weathering desert plants. I. Root colonization and weathering of igneous rocks. Int. J. Plant Biol. 2004; 6, 629-42. 
http://wjst.wu.ac.th

[18] C Thongponkaew, N Chittamart, S Tawornpruek and P Pinjai. Screening of phosphate-solubilizing bacteria from sugarcane rhizospheric soil and their abilities to improve growth and yield of sugarcane. Proc. Int. Soc. Sugar Cane Tech. 2016; 29, 1329-37.

[19] GP Meade and JC Chen. Cane sugar handbook. $10^{\text {th }}$ eds. Wiley Interscience/Wiley, New York. 1977, p. 947.

[20] RB Mathur. Handbook of cane sugar technology. $2^{\text {nd }}$ eds. Oxford and IBH Publishing, New Dehli. 1975 , p. 651.

[21] RH Bray and L Kurtz. Determination of total, organic, and available forms of phosphorus in soils. Soil Sci. 1945; 59, 39-46.

[22] RL Westerman. Soil testing and plant analysis. $3^{\text {rd }}$ eds. Soil Science Society of America Book, Wisconsin, USA. 1991, p. 137.

[23] H Zhang and JL Kovar. Fractionation of soil phosphorus. In: JL Kovar and GM Pierzynski (Eds.). Methods of phosphorus analysis for soils, sediments, residuals, and waters. Virginia Tech University, USA, 2009, p. 50-60.

[24] CS Nautiyal. An efficient microbiological growth medium for screening phosphate solubilizing microorganisms. FEMS Microbiol. Lett. 1999; 170, 265-70.

[25] S Munda, BG Shivakumar, B Gangaiah, KM Manjaiah, DS Rana, J Layek and L Koneru. Influence of direct and residual phosphorus fertilization on growth and yield of potato in a soybean-potato cropping system. Aust. J. Crop Sci. 2015; 9, 191.

[26] MK Abbasi, N Musa and M Manzoor. Mineralization of soluble P fertilizers and insoluble rock phosphate in response to phosphate-solubilizing bacteria and poultry manure and their effect on the growth and P utilization efficiency of chilli (Capsicum annuum L.). Biogeosciences 2015; 12, 460719.

[27] N Moradi and SM Rasouli. Effect of Phosphate-solubilizing bacteria (PSB) on distribution of phosphorus forms in a calcareous soil. Appl. Soil Res. 2019; 7, 67-81.

[28] E Khare and NK Arora. Effects of soil environment on field efficacy of microbial inoculants. Springer, New Delhi. 2015, p. 353-81.

[29] A Ahmad, M Imran, S Hussain, S Mahmood and AH Houssein. Bacterial impregnation of mineral fertilizers improves yield and nutrient use efficiency of wheat. J. Sci. Food Agr. 2017; 97, 3685-90.

[30] M Adnan, Z Shah, S Fahad, M Arif, M Alam and IA Khan. Phosphate-solubilizing bacteria nullify the antagonistic effect of soil calcification on bioavailability of phosphorus in alkaline soils. Sci. Rep-uk. 2017; 7, 16131.

[31] KB Selvi, JJA Paul, V Vijaya and K Saraswathi. Analyzing the efficacy of phosphate solubilizing microorganisms by enrichment culture techniques. Biochem. Mol. Biol. Int. 2017; 3, 1.

[32] EB Santana, ELS Marques and JCT Dias. Effects of phosphate-solubilizing bacteria, native microorganisms and rock dust on Jatropha curcas L. growth. Genet. Mol. Res. 2016; 15, 4.

[33] G Kaur and SM Reddy. Role of phosphate-solubilizing bacteria in improving the soil fertility and crop productivity in organic farming. Arch. Agron. Soil Sci. 2014; 60, 549-64.

[34] F Wu, J Li, Y Chen, L Zhang, Y Zhang, S Wang and J Liang. Effects of phosphate solubilizing bacteria on the growth, photosynthesis, and nutrient uptake of Camellia oleifera Abel. Forests 2019; $10,348$.

[35] S Noor, M Yaseen, M Naveed and R Ahmad. Effectiveness of diammonium phosphate impregnated with Pseudomonas putida for improving maize growth and phosphorus use efficiency J. Anim. Plant Sci. 2017; 27, 1-8.

[36] G Kalayu. Phosphate solubilizing microorganisms: Promising approach as biofertilizers. Int. J. Res. Agron. 2019; 2019, 4917256. 